\title{
NPO Governance Case
}

\author{
by J. Augusto Felício \\ (Portugal)
}

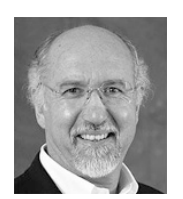

and Ricardo Rodrigues

(Portugal)

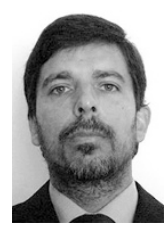

ISEG, Lisbon School of Economics and Management

International Center for Corporate Governance

The demographic shift (rise in average life expectancy and declining birth rate), together with changes in family structure and the recent economic difficulties facing many families, has increased demands on social organizations. These greater demands highlight the importance of social organizations in ensuring social cohesion and well-being. In addition, constraints on public expenditure mean fiercer competition for financial resources and greater difficulties in accessing these resources. Accordingly, some of the burden has fallen upon families to bear the costs of services provided by social sector organizations, which must seek alternative sources of financing.

$\mathrm{CAJIL}^{1}$ is a nonprofit organization devoted to supporting the senior population in one of the largest parishes in the city of Lisbon (Portugal). Like many organizations that provide similar services ${ }^{2}$, CAJIL must cater to the interests of a wide range of stakeholders, including users, CAJIL members, and the government. (1) Users are vulnerable individuals who require the services provided in CAJIL facilities or in their own homes. The amount these users pay depends on their income. (2) CAJIL members aim to provide sociocultural support for the population through CAJIL's work. (3) The government seeks the well-being of the population. Through social security services, the government establishes the rules and allocates the necessary financing to allow social organizations to function. In addition to these stakeholders, the highly specialized professionals who work in social organizations must also be considered. These professionals pursue the goals of career development, remuneration, and stability.

Founded in 1986, CAJIL has been gradually increasing its number of users and the number of services available to these users. The principal limitations in this regard are legislation governing CAJIL's operations and government funding. Since

\footnotetext{
${ }^{1}$ Center for support to young and senior people of Lumiar.

${ }^{2}$ In Portugal, private organizations in the social sector are generally small, which often means greater proximity to users, and directors usually participate voluntarily.
} 
1986, the leadership has mostly come from the current chair of the board of directors (either as chair or briefly as vice-chair). The chair of the board of directors is a university professor with extensive management experience, a strong orientation toward CAJIL's development and engagement from top managers and other employees, and wide recognition within the local community. CAJIL's board of directors, elected for 3-year terms, is formally constituted by five directors who carry out their duties on a voluntary basis. CAJIL's board, in particular the chair, oversees operations, the definition of strategic guidelines, including the selection and recruitment of top managers (technical manager, administrative and financial manager, and social marketing manager), and external representation, especially in matters related to social security services.

CAJIL's board of directors is currently implementing a large-scale investment project to build high-quality facilities while increasing the number of services (including services that are scarce in the city of Lisbon) and number of users. Implementing this project exceeds the length of a mandate, and the project's lifetime may exceed 50 years. To support this investment, CAJIL must have a governance structure that assures investors and the implicated public institutions that CAJILnot just the current board of directors and chair-is capable of completing the project and responding to the management challenges associated with the increase in activity and complexity linked to this investment.

\section{$1 \quad$ What Are the Main Causes of This Problem?}

Because of the aforementioned issues, in recent years, the rotation of vulnerable users who access CAJIL's services has grown, although these users and their families are not involved in CAJIL's activities (e.g., participation in general assemblies). Therefore, despite the growing number of users, the membership base, which defines CAJIL's goals through participation in general assemblies and the board, has remained stable. The average age of members is growing, and the membership base is becoming decreasingly dynamic. The amount of time devoted by board members, in particular the chair, has steadily grown because of greater responsibility and breadth of activities, both of which are expected to increase in the coming years. CAJIL therefore increasingly depends on the current chair in operational matters and, specially, in terms of strategic issues. The chair also wants to ensure that his legacy lasts and that his decades of effort and dedication are not wasted.

\section{What Do You Recommend to Solve This Problem in an Effective Way?}

As well as implementing the project that is currently under development and conducting all other activities, the board should focus on the membership base, mobilizing members and targeting their involvement in CAJIL's activities. A larger 
membership base for recruiting board members would enable the identification of individuals who are willing and able to perform their duties as directors, have management and social skills, and command prestige and recognition within the community - a necessary condition to ensure that activities meet users' needs. The board of directors should also create conditions to enable a gradual transition over the next 10 to 15 years, allowing the chair to act increasingly as an advisor to the remaining board members.

\section{$3 \quad$ What Happened in Reality?}

The board that was appointed in 2016 for a 3-year term has great diversity in terms of members' education, professional activities (economics, engineering, management, medicine, and nursing), and age, which ranged from 30 to nearly 70 . In addition to the chair, the board has members who already have experience on CAJIL's board and others who are appearing on the board for the first time. The main aim is to equip younger members with the necessary skills and experience to ensure the continuity of ongoing activities and projects.

\section{$4 \quad$ What Are the Most Important Lessons Learned from This Case?}

Traditional governance mechanisms are not applicable to all organizations. For most nonprofit organizations, remuneration cannot be used to recruit directors who handle operational and strategic issues. Likewise, interests cannot be aligned through remuneration or equity ownership. Finally, although directors perform their duties on a voluntary basis, their professional reputation is under scrutiny. Therefore, their commitment and responsibility must be akin to their commitment and responsibility in professional, remunerated activities.

Unlike in traditional companies where shareholders have financial incentives to monitor company activity, in associations, all members have equal voting rights, so they lack obvious incentives to monitor activity. Consequently, the power tends to shift from the members to the board. Regular elections, however, mean that the board can easily be replaced, although replacing the board fails to guarantee the competence and commitment of the new board.

It is therefore important to stimulate the debate on governance of nonprofit organizations. Nonprofit organizations play a key role in society, so their governance is, by extension, crucial for society. Healthy debate over their governance can provide governance mechanisms that reconcile the voluntary nature of the board members with the dispersion of voting rights and the development of medium- and long-term strategies to ensure that these organizations meet their goals. 
Open Access This chapter is licensed under the terms of the Creative Commons Attribution 4.0 International License (http://creativecommons.org/licenses/by/4.0/), which permits use, sharing, adaptation, distribution and reproduction in any medium or format, as long as you give appropriate credit to the original author(s) and the source, provide a link to the Creative Commons licence and indicate if changes were made.

The images or other third party material in this chapter are included in the chapter's Creative Commons licence, unless indicated otherwise in a credit line to the material. If material is not included in the chapter's Creative Commons licence and your intended use is not permitted by statutory regulation or exceeds the permitted use, you will need to obtain permission directly from the copyright holder.

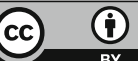

